\title{
Freedom of Establishment and the Freedom to Provide Services in the EU
}

\author{
Armin Cuyvers
}

\subsection{Services: The New Economic Epicenter}

When the internal market was established, the European economy primarily revolved around goods. ${ }^{1}$ The free movement of services, therefore, was considered to be a residual freedom that applied where the other freedoms did not. ${ }^{2}$ In the age of Google and Goldman Sachs, this picture has drastically changed. Services now constitute over 70\% of the European economy. Consequently, the free movement of services has also significantly increased in importance.

Considering the increasing importance of services for the EAC as well, this Chapter primarily focuses on the free movement of services as gradually developed by the CJEU. For as we will see, the enormous pluriformity of services, ranging from abortion to construction and from banking to healthcare, raises all kinds of challenges, certainly when one tries to apply the same standard internal market test to all of them. The freedom of services has also given rise to one of the most contested and contorted pieces of $\mathrm{EU}$ legislation so far, the Services Directive. In addition to services, this Chapter also covers the main elements of the freedom of establishment, which is closely connected to services. $^{3}$

\subsection{The Freedom to Provide Services}

This section first discusses the freedom to provide services as laid down in the TFEU and developed by the CJEU. It subsequently outlines what are considered

1 See EU Chapters 9 and 10.

2 This original position can still be seen in the formulation of Article $57 \mathrm{TFEU}$, and interestingly the residual nature of services seems to have carried over to the EAC as well, see Chapter 12.

3 See for further reading amongst many others V. Hatzopoulos, Regulating Services in the European Union (OUP, 2012) or I. Liaonos and O. Odudu, Regulating Trade in Services in the EU and the WTO: Trust, Distrust and Economic Integration (CUP, 2012). 
restrictions to the free movement of services and how these may be justified. Lastly, the Services Directive is briefly introduced, as it forms one example from EU law that the EAC might not necessarily want to fully emulate.

\subsection{The Freedom to Provide Services: Treaty Basis}

The freedom to provide services is laid down in Article 56 TFEU:

Within the framework of the provisions set out below, restrictions on freedom to provide services within the Union shall be prohibited in respect of nationals of Member States who are established in a Member State other than that of the person for whom the services are intended. ${ }^{4}$

Article 57 TFEU adds that:

Services shall be considered to be "services" within the meaning of the Treaties where they are normally provided for remuneration, in so far as they are not governed by the provisions relating to freedom of movement for goods, capital and persons. (...) Without prejudice to the provisions of the Chapter relating to the right of establishment, the person providing a service may, in order to do so, temporarily pursue his activity in the Member State where the service is provided, under the same conditions as are imposed by that State on its own nationals.

As with the other freedoms, Article 56 and 57 TFEU only provide a very general outline. As a result, it was up to the CJEU to further develop several key issues, including the concept of a service itself, the demarcation between services and establishment and the question of who is allowed to rely on the freedom to provide services.

\subsection{The Concept of a Service}

Services are defined in the Treaty as all economic activities that are normally provided for remuneration and that are not covered by the other freedoms.

4 Article 56 TFEU has vertical direct effect, see already Case 33/74 Van Binsbergen [1974] ECR 129, par. 26. The horizontal effect has not yet been explicitly accepted by the CJEU, as will be discussed further below. 
The definition of a service therefore turns on two points: 1) what counts as an economic activity for remuneration and 2) what distinguishes a service from the other freedoms, especially from establishment?

\subsubsection{An Economic Activity for Remuneration}

To qualify as a an economic activity it suffices that an activity is normally done in return for some form of consideration. ${ }^{5}$ This consideration may be very little and does not even have to be in money, nor is it required that the service provider seek to make a profit. ${ }^{6}$ The CJEU has also found that the consideration itself does not have to be paid by the person receiving the service. The only thing that matters is that the provider receives some form of consideration, not who pays it. ${ }^{7}$ Consequently, the consideration may also be paid by a third party, including by the state. This is a particularly important extension of the concept of a service. It means that all kinds of semi-public services, such as healthcare or education, that are provided by private parties but paid for by the state or public insurance schemes, may fall under the free movement of services. ${ }^{8}$ Even these sensitive political areas, therefore, have to comply with the EU rules on free movement, and may in principle not restrict foreign providers. Only where an activity is fully provided by the state itself, such as in the case of public schools run by the government, it does not constitute a service and therefore falls outside the scope of free movement law. ${ }^{9}$

More generally, the moral dubiousness or political sensitivity of an activity does not remove it from the scope of Article 56 TFEU. As long as an activity is legal and normally provided for remuneration, it qualifies as a service. ${ }^{10}$ Consequently, the case law on services reaches some of the more contested

5 See inter alia Case 263/86 Humbel [1988] ECR 5365, par. 17, Case C-422/o1 Skandia and Ramstedt [2003] ECR I-6817, par. 23, and Case C-76/05 Schwarz and Gootjes-Schwarz [2007] ECR I-0000, par. 38.

6 See Case C-157/99 Smits and Peerbooms [2001] ECR I-5473, paras. 50 and 52 as well as Case C-281/o6 Jundt ECLI:EU:C:2007:816.

7 Case 352/85 Bond van Adverteerders and Others [1988] ECR 2085, par. 16, and Joined Cases C-51/96 and C-191/97 Deliège [200o] ECR I-2549, par. 56, Smits en Peerbooms par. 58.

8 Case C-157/99 Smits and Peerbooms [2001] ECR I-5473, par. 55, Case C-385/99 MüllerFauré [2003] ECR I-4509, ECLI:EU:C:2003:270, par. 103, and especially Case C-372/04 Watts [2006] ECLI:EU:C:2006:325. Also see on this point G. Davies, 'Welfare as a Service' (2002) 29 LIEI 27.

9 Case C-263/86 Humbel [1988] ECR 5365. Case C-109/92 Wirth, however, determined that private education can form a service under art. $56 \mathrm{TFEU}$.

10 On the exclusion of illegal activities from free movement law see inter alia Case C-137/o9 Josemans [2010] ECR I-13019. 
and/or colorful outer reaches of human activity, including abortion, gambling and prostitution..$^{11}$ Grogan, for example, concerned students handing out information on UK abortion clinics in Ireland. At that time, abortions were illegal in Ireland, as was going abroad for an abortion. This prohibition was based on a moral conviction widely shared by the Irish population, and was laid down in the Irish constitution, yet the large majority of other Member States allowed abortion. ${ }^{12}$ Sidestepping the fierce debate on the morality of abortion, the CJEU focused on legality and remuneration to determine if abortion qualified as a service:

Whatever the merits of those argument on the moral plane, they cannot influence the answer to the national court's first question. It is not for the Court to substitute its assessment for that of the legislature in those Member States where the activities in question are practised legally. ${ }^{13}$

Abortion was a 'medical activity which is normally provided for remuneration' and was 'lawfully practiced in several Member States', and therefore qualified as a service. ${ }^{14}$ As the relation between the students and the economic activity of the abortion clinic was too remote, however, in this particular case the students could not rely on Article $56 \mathrm{TFEU}$, providing the CJEU an escape from this moral, legal and political dilemma. ${ }^{15}$ After this judgment, a Treaty protocol was adopted that provided legal protection to the Irish ban on abortion against free movement law, providing a targeted political solution without reducing the scope of Article 56 TFEU in general.

The CJEU has been equally been unwilling to limit the scope of Article ${ }_{5}^{6}$ TFEU based on the social or political sensitivity of certain services. ${ }^{16}$ Both

11 Case C-159/9o, Grogan ECLI:Eu:C:1991:378, Case C-268/99 Jany ECLI:Eu:C:2001:616, or Case C-42/07 Liga Portuguesa ECLI:Eu:C:2009:519. For a discussion on the ensuing struggle of the CJEU in the area of gambling see S.C.G. Van den Bogaert and A. Cuyvers: 'Money For Nothing: The Case Law of the EU Court of Justice on the Regulation of Gambling' Common Market Law Review (2011) 48 (4), 1175.

12 Grogan, par. 19.

13 Grogan, par. 20, emphasis added.

14 Grogan, par. 18 and 21.

15 Similarly see Case C-275/92 Schindler ECLI:Eu:C:1994:119, par. 32, where the CJEU held that 'Even if the morality of lotteries is at least questionable, it is not for the Court to substitute its assessment for that of the legislatures of the Member States where that activity is practised legally.'

16 Case 33/74 Van Binsbergen [1974] ECR 129, Case 279/80 Webb [1981] ECR 3305, par. 10, and Kohll, paragraph 20. 
healthcare and education, for example, have been brought under the scope of Article 56 TFEU, even where this brought the CJEU into contested terrain. ${ }^{17}$ For example, as healthcare forms a service, individuals may in principle not be restricted from seeking medical treatment in other Member States, which also means that this treatment abroad should, under certain conditions, be covered by national health insurance. ${ }^{18}$

In line with the other freedoms, therefore, the CJEU has developed a very broad definition of a service, and in doing so has greatly extended the scope of Article 56 TFEU. A great many activities qualify as services and therefore are in principle entitled to free movement. As we will see below, however, in return for this very broad concept of a service, the CJEU is often more lenient when assessing restrictions on services in more contested areas.

\subsubsection{Distinguishing Services from Other Freedoms: Temporary Nature}

Article 57 TFEU provides that an activity only qualifies as a service where it is not covered by one of the other freedoms. The primary difficulty in this regard is to distinguish services from establishment. ${ }^{19}$ Say for example that a Spanish architect moves to Austria for four months to assist in a large building project, renting a turn-key office space for the duration of his stay. Is he 'merely' a provider of services or has he established himself in Austria?

The essential difference between services and establishment is the temporary nature of the activity. Services are intended to be temporary and limited in time. Establishment, on the other hand, is intended to be more permanent and open-ended. Yet in practice it can be difficult to differentiate between the two. The leading, if not always conclusive, judgment on the difference between services and establishment is Gebhard, which concerned a German lawyer

17 See for healthcare Joined Cases 286/82 \& 26/83, Luisi and Carbone [1984] ECR 377, par. 16, Case C-158/96 Kohll [1998] ECR I-1931) ECLI:EU:C:1998:171, par. 21, Case C-368/98 Vanbraekel [2001] ECR I-5363, Case C-157/99 Geraets-Smits and Peerbooms [2001] ECR I-5473, C-385/99 Müller-Fauré [2003] ECR I-4509, Case C-372/04 Watts [2006] ECR I-4325 and Case C-444/05 Stamatelaki [2007] ECR I-3185) ECLI:EU:C:2007:231. The Court does make a distinction, however, between hospital and non-hospital healthcare. See also J.W. van de Gronden et al. (eds.), Health Care and EU Law (The Hague: Asser, 2011). For education see Case C-109/92 Wirth [1993] ECR I-6447, paragraphs 15 and 16 and Case C-76/05 Schwarz [2007] ECR I-6849.

18 See also the discussion below on the justification of possible restrictions in this regard.

19 See for financial services and capital Case C-452/04 Fidium Finanz [2006] ECR I-9521, ECLI:EU:C:2006:631. 
working in Italy. ${ }^{20}$ On determining whether Gebhard had established himself in Italy or had remained a service provider the cJEU held the following:

As the Advocate General has pointed out, the temporary nature of the activities in question has to be determined in the light, not only of the duration of the provision of the service, but also of its regularity, periodicity or continuity. The fact that the provision of services is temporary does not mean that the provider of services within the meaning of the Treaty may not equip himself with some form of infrastructure in the host Member State (including an office, chambers or consulting rooms) in so far as such infrastructure is necessary for the purposes of performing the services in question.

However, that situation is to be distinguished from that of Mr Gebhard who, as a national of a Member State, pursues a professional activity on a stable and continuous basis in another Member State where he holds himself out from an established professional base to, amongst others, nationals of that State. Such a national comes under the provisions of the chapter relating to the right of establishment and not those of the chapter relating to services. ${ }^{21}$

In our example of the Spanish architect moving to Austria, therefore, the architect would still qualify as a service provider. At the same time, Gebhard does not mean that the provision of a service can never last for a very long time. In Schnitzer, for example, a Portuguese company carried out plastering in Germany for almost three years but still qualified as a service provider:

Thus, 'services' within the meaning of the Treaty may cover services varying widely in nature, including services which are provided over an extended period, even over several years, where, for example, the services in question are supplied in connection with the construction of a large building. Services within the meaning of the Treaty may likewise be constituted by services which a business established in a Member State supplies with a greater or lesser degree of frequency or regularity, even over an extended period, to persons established in one or more other Member States, for example the giving of advice or information for remuneration. $(\ldots)$

20 Case C-55/94 Gebhard ECLI:Eu:C:1995:411.

21 See also Case C-131/o1 Commission v Italy [2003] ECR I-1659, paragraph 22. 
It follows that the mere fact that a business established in one Member State supplies identical or similar services with a greater or lesser degree of frequency or regularity in a second Member State, without having an infrastructure there enabling it to pursue a professional activity there on a stable and continuous basis and, from the infrastructure, to hold itself out to, amongst others, nationals of the second Member State, is not sufficient for it to be regarded as established in the second Member State. ${ }^{22}$

No simple criterion or clear time limit exists, therefore, yet the establishment of infrastructure seems to be of particular importance for crossing the thin line between services and establishment. ${ }^{23}$ Because of the grey area between both freedoms, it may in some cases be difficult to predict which of the two applies. Considering the significant convergence between the freedoms, however, it will usually also not make a real difference, in terms of outcome, which freeform applies. ${ }^{24}$ Sometimes, the CJEU does not even deem it necessary to choose between services and establishment, and simply applies both. ${ }^{25}$

\subsection{Who may Rely on Article 56 TFEU?}

Once something qualifies as a service, the question remains which individuals are entitled to rely on Article 56 TFEU to demand the free movement of this service. When Article 56 TFEU was drafted, the scenario envisioned was that of a service provider traveling to a customer in another Member State. It would then be the service provider that would rely on Article 56 TFEU to contest any restrictions to her free movement. ${ }^{26}$ In Luisi and Carbone, however, the CJEU held that not just service providers but also service recipients may rely on Article 56 TFEU. ${ }^{27}$ This case concerned Italian citizens vacationing in

22 Case C-215/01 Schnitzer ECLI:Eu:C:2003:662, paras 30-32. Also see Case C-458/o8 Commission v. Portugal [2010] ECR I-11599.

23 See already Case 205/84 Commission v. Germany (Insurance Services), where the CJEU also clarified that establishment does not require a formal branch or agency, but that an office or permanent representative may suffice.

24 See EU Chapter 9 on the gradual convergence between the freedoms.

25 See for example Case C-136/oo, Danner ECLI:EU:C:2002:558, or Case C-334/o2, Commission v. France ECLI:EU:C:2004:129. For a possible combination of services and goods see Case C-403/o8 Football Association Premier League ECLI:EU:C:2011:631, par. 79 or Case C-39o/99 Canal Satélite Digital [2002] ECR I-607, paras. 29 to 33.

26 . See also the early case law of the CJEU fort his assumption, for example Case 33/74 van Binsbergen ECLI:EU:C:1974:131 or Case 76/81, SA Transporoute et travaux ECLI:EU:C:1982:49. .Joined Cases 286/82 \& 26/83, Luisi and Carbone [1984] ECR 377. 
Germany and France, where they inter alia received some medical treatment. Because they had received services there, they could rely on the free movement of services to challenge Italian laws restricting the export of foreign currency:

It follows that the freedom to provide services includes the freedom, for the recipients of services, to go to another Member State in order to receive a s service there, without being obstructed by restrictions, even in relation to payments and that tourists, persons receiving medical treatment and persons travelling for the purpose of education or business are to be regarded as recipients of services. ${ }^{28}$

As a result of this landmark judgment, all individuals that travel to another Member State and receive some kind of services may rely on the free movement of services. ${ }^{29}$ Moreover, any national entities that provide a service to such visitors from other Member States may also rely on Article 56 T FEU. For example, if a group of Luxemburgish tourists come to Amsterdam and take a tour on a canal boat, both these tourists and the operator of the canal boat fall under the scope of the free movement of services, and can hence rely on Article 56 TFEU to challenge any restriction they may encounter. ${ }^{30}$ As most people that travel to another Member State will receive at least some services, such as transport, lodging or restaurant services, this line of case law has greatly expanded the scope of Article 56 TFEU.

At the same time, the scope of the freedom to provide services does have its limits. To begin with, Article 56 TFEU only applies where a cross-border element is present. Purely internal situations, such as a small Hungarian law firm providing legal advice to a local Hungarian company, are not covered by the freedom to provide services. ${ }^{31}$ Four possible cross-border scenarios can be envisioned. ${ }^{32}$ Firstly, the service provider may travel to another Member

\footnotetext{
28 Joined Cases 286/82 and 26/83 Luisi and Carbone [1984] ECR 377, par. 16.

29 See in this regard also Case C-158/96 Kohll [1998] ECR I-1931, Case Case C-372/04 Watts [2006] ECR I-4325 and especially Case 186/87 Cowan [1989] ECR 195 where the specific services received by a British tourist did not even have to be specified.

30 See for example Case C-98/14 Berlington ECLI:Eu:C:2015:386, paras. 25 and 26 and Joined Cases C-340/14 and Case C-341/14 Trijber ECLI:EU:C:2015:641.

31 Cf. Case C-108/98 RI.SAN. [1999] ECR I-5219; ECLI:Eu:C:1999:400 or Case 52/79 Debauve [1980] ECR 83 .

32 Compare also the four 'modes' under the Common Market Protocol Schedule of Commitment on the Progressive Liberalisation of Services (Annex v), as discussed in Chapter 12 par. 2.
} 
State to provide a service. ${ }^{33}$ Secondly, under Luisi and Carbone, service recipients may travel to another Member State to receive a service. Thirdly, the service itself may cross a border, for example via the internet. ${ }^{34}$ Fourthly, the service provider and the service recipient may travel together to another Member State, for example with an Irish consultant joining his Irish client on a business trip to Malta. ${ }^{35}$

In addition, Article $5^{6} \mathrm{TFEU}$ only covers service providers that have the nationality of a Member State and are established in a Member State. ${ }^{36}$ Service recipients, however, do not have to meet the double requirement of nationality and establishment. Even third-country nationals, therefore, can rely on article $56 \mathrm{TFEU}$ when they receive a service from an EU provider. ${ }^{37} \mathrm{~A}$ Rwandese businesswoman in Brussels may, for example, rely on article $56 \mathrm{TFEU}$ when receiving lobbying services from a UK law firm. Lastly, it seems that Article 56 TFEU still only has vertical direct, as its horizontal direct effect remains uncertain. ${ }^{38}$

\subsection{Restrictions on the Free Movement of Services}

The concept of a restriction under Article $56 \mathrm{TFEU}$ is functionally similar to the very broad concept developed by the CJEU in Dassonville for goods, and also focuses on market access. ${ }^{39}$ The standard definition was provided in Säger, were the CJEU held that Article 56 TFEU requires:

33 Note that here it is not required that the specific service recipient in that other ms has already been identified. Mere offers of services, without any identified customers as yet, therefore also fall under the freedom. See Alpine investments par. 19. In addition, Art. 56 TFEU also applies if a customer moves to another Member State, and hence the service relationship acquires a cross-border element. See Case 15/78 Koestler [1978] ECR 1971) ECLI:EU:C:1978:184.

34 Refs Alpine Investments par. 22.

35 Cf. Case C-154/89, Commission v. France ECLI:Eu:C:1991:76 or Case C-398/95, Syndesmos ton en Elladi Touristikon kai Taxidiotikon Grafeion ECLI:EU:C:1997:282.

36 See however also the other rights Union citizens and their family members may derive from their citizenship, as discussed in EU Chapter 11.

37 . Case C-484/93, Svensson and Gustavsson ECLI:EU:C:1995:379.

38 For vertical direct effect see Case 33/74 Van Binsbergen [1974] ECR 1299, par. 27. For the complex case law on horizontal or quasi-horizontal effect see inter alia Case C-309/99 Wouters [2002] ECR I-1577, par. 120, Case 36/74 Walrave and Koch [1974] ECR 1405 and especially Case C-341/05, Laval ECLI:EU:C:2007:809.

39 See Eu Chapter 10 as well as Case C-39o/99 Canal Satélite ECLI:Eu:C:2002:34 and T. Connor, 'Goods, Persons, Services and Capital in the European Union: Jurisprudential Routes to Free Movement' (2010) 11 German Law Journal, 159. For the earlier case law of the CJEU on this point, which differentiated more between indirect discrimination and 
(...) the abolition of any restriction even if it applies without distinction to national providers of services and to those of other Member States, when it is liable to prohibit or otherwise impede the activities of a provider of services established in another Member State where he lawfully provides similar services. ${ }^{40}$

No discrimination is therefore required, the criterion only being if there is a chance that a national measure will make it more difficult to provide or receive cross-border services..$^{41}$ Importantly, this concept also covers any national rule that creates a so-called 'double burden' by replicating safeguards already in place in the home state of the service provider. Consequently, Member States may in principle not impose their own regulations on a foreign service provider on points where the provider is already regulated by its home state. ${ }^{42}$ Otherwise, the mere duplication of national rules and requirements would in itself already restrict free movements, such as a free lance pilot that would have to make training hours in five different Member States.

Article 56 TFEU not only provides service providers the right to enter and reside in the Member State, but also to bring all staff they use for providing the service, including Third Country National (TCN) staff. ${ }^{43}$ Accidentally, this inclusion of free movement rights for service providers and their staff also means that, if the UK wants to retain the free movement of services after Brexit, they would indirectly also accept a significant amount of free movement of persons.

Although the scope of the prohibition under Article $56 \mathrm{TFEU}$, therefore, is at least as broad as that under Article $34 \mathrm{TFEU}$ concerning goods, the CJEU has not extended the Keck exception to services. ${ }^{44}$ Consequently, as with the other

non-discriminatory measures, see S.C. Barnard, The Substantive Law of the EU. The Four Freedoms (4th edn, Ou P 2015), 387 a.o.

$40 \quad$ Case C-76/9o Säger [1991] ECR I-4221, par. 12.

41 See also Case C-42/07 Liga Portuguesa ECLI:Eu:C:20og:519and Case C-384/93 Alpine Investments ECLI:EU:C:1995:126.

42 See for example Case C-272/94, Michel Guiot and Climatec ECLI:Eu:C:1996:147.

43 Case C113/89 Rush Portuguesa [1990] ECR I-1417, par. 12, as well as Cases 62/81 and 63/81 Seco and Desquenne \& Giral v Etablissement d' Assurance contre la Vieillesse et l' Invalidité [1982] ECR 223, Case C-355/98 Commision v. Belgium [2000] ECR I-1221, and Case C-43/93 Vander Elst [1994] ECR I-3803, par. 21. For the question which labour standards and social laws apply, see Directive $96 / 71 / \mathrm{EC}$ concerning the posting of workers in the framework of the provision of services [1996] oJ L18/1 as well as Case C-341/05, Laval ECLI:EU:C:2007:809.

44 See for example Joined Cases C-34-36/95 De Agostini ECLI:Eu:C:1997:344, Case C-275/92 Schindler ECLI:EU:C:1994:119 or Case C-384/93 Alpine Investments ECLI:EU:C:1995:126. For the Keck exception see EU Chapter 10, par. 4.1. See also W.H. Roth, 'The European Court 
freedoms, the main legal debate takes place over the issue of justification, not so much over the existence of a restriction itself.

\subsection{Justifications of Restrictions on the Free Movement of Services}

As with the other freedoms, a restriction on Article $5^{6} \mathrm{TFEU}$ can be justified if it serves a legitimate aim in a proportionate manner. ${ }^{45}$ For services as well, the legitimate aims allowed under Article $5^{1}$ and 52 TFEU have been judicially complemented by an open category of rule of reason exceptions. ${ }^{46}$ Under the rule of reason, the CJEU has already accepted a great variety of aims that may justify a restriction, including consumer protection, ${ }^{47}$ cultural policy, ${ }^{48}$ preventing abuse of free movement of services, ${ }^{49}$ professional rules protecting the recipient of services, ${ }^{50}$ or the right to take collective action for the protection of the workers of the host State against possible social dumping. ${ }^{51}$ The one main limit is that purely economic aims, such as safeguarding revenue or protecting a certain economic sector, cannot form legitimate aims under the rule of reason..$^{52}$ In addition, as in the case of goods, the orthodox doctrine holds

of Justice's Case Law on Freedom to Provide Services: is Keck Relevant?', in M. Andenas, W.-H. Roth, Services and Free Movement in EU Law (OuP, 2002), 1.

45 See amongst many others Case C-678/11 Commission v Spain ECLI:Eu:C:2014:2434, Case C-523/12 Dirextra Alta Formazione ECLI:Eu:C:2013:831, par. 24 or Joined Cases C-369/96 and C-376/96 Arblade [1999] ECR I-8453, par. 35 .

46 For the rule of reason exceptions see Case C-76/9o Säger [1991] ECR I-4221. On the strict application of the Treaty exceptions see for example Case $\mathrm{C}-3 / 88$, Commission $v$. Italy eCLI:Eu:C:1992:235, Joined Cases C-430 \& 431/99 Sea-Land Service ECLI:Eu:C:2002:364, Case C-158/96 Kohll ECLI:Eu:C:1998:171, or Case C-465/05 Commission v. Italy ECLI:EU: C:2007:781, par. 49 .

47 Case 220/83 Commission v. France eCli:Eu:C:1986:461, Case C-393/o5 Commission v. Austria ECLI:EU:C:2007:722, or Case C-404/05 Commissionv. Germany ECLI:EU:C:2007:723.

48 Case C-154/89 Commission v. France ECLI:Eu:C:1991:76, Case C-125/06 Commission v. Infront [2008] ECR I-1451, or Case C-195/o6 KommAustria v. ORF [2007] ECR I-8817.

49 Case C-244/04 Commission v. Germany [2006] ECR I-885, par. 38.

$50 \quad$ Case 33/74 Van Binsbergen ECLI:EU:C:1974:131, Case C-19/92 Kraus ECLI:EU:C:1993:125, or Case C-309/99 Wouters ECLI:EU:C:2002:98.

$51 \quad$ Case C-341/05, Laval ECLI:EU:C:2007:809.

$5^{2}$ See inter alia Case C-338/og Yellow Cab ECLI:Eu:C:2010:814, or Case C-347/og Dickinger and Ömer ECLI:EU:C:2011:582. The risk of seriously undermining the financial balance of the social security system does, however, constitute a legitimate aim. See for example Case C-157/99 Smits and Peerbooms ECLI:Eu:C:2001:404 and Case C-372/04 Watts ECLI: EU:C:2006:325. 
that directly discriminatory measures can only be justified under Treaty-based exceptions, whereas the rule of reason can only justify indistinctly applicable measures. ${ }^{53}$

One of the main perculiarties in the justification of services, however, is the variation in leeway offered to Member States depending on which service is at stake. This leeway is especially granted via a more relaxed application of the proportionality test, which requires that a restriction is both suitable and necessary to achieve its objective. ${ }^{54}$ These open criteria allow the court to increase or reduce its scrutiny, which in turn allows the CJEU to tweak the formally one-size-fits-all free movement test for different services. In more economic or standard commercial areas, and therefore the majority of cases, the application of the proportionality test is usually very strict, for instance requiring Member States to proof that there really was no less restrictive alternative. ${ }^{55}$ In more sensitive areas, the CJEU sometimes satisfies itself with a more limited review, merely checking if the national measure is not manifestly inappropriate. ${ }^{56}$ The clearest example of the significant leeway the CJEU can create for Member States, whilst formally remaining within the standard internal market test, can be found in the context of gambling, where Member States have received all but a carte blanche to regulate games of chance. ${ }^{57}$ This variation in scrutiny allows for the necessary flexibility in such a diverse field as services, but of course also comes at a cost of legal certainty.

53 See for example Case C-353/89 Commission v. Netherlands ECLI:EU:C:1991:325, or Case C-451/99 Cura Anlagen ECLI:Eu:C:2002:195, as well as S. O'Leary and J.M. FernándezMartín, 'Judicially-Created Exceptions to the Free Provision of Services', in M. Andenas, W.-H. Roth, Services and Free Movement in EU Law (ouP, 2002), 163. For cases that do not fit this pattern, see for example Case C-118/96 Safir ECLI:EU:C:1998:170.

54 See for example Case C-49/98 Finalarte ECLI:EU:C:2001:564. The suitability test also includes the requirement of consistency, meaning that the measure may be internally inconsistent or in part undermine the very objective it is trying to realize. See Case C-243/o1 Gambelli ECLI:EU:C:2003:597, par. 68.

55 Case C-678/11 Commission v Spain ECLI:EU:C:2014:2434, par. 43.

56 See for example Case C-262/o2 Commission v. France (Loi Evin) ECLI:Eu:C:2004:431, especially the reasoning in paras $33^{-}-39$.

57 See for an overview S.C.G. Van den Bogaert and A. Cuyvers: 'Money For Nothing: The Case Law of the EU Court of Justice on the Regulation of Gambling' (2011) 48 (4) Common Market Law Review, 1175, and for recent developments which may herald some increased scrutiny, S.C.G.Van den Bogaert and A. Cuyvers, 'Let it be? The regulation and allocation of gambling licenses at the EU and Member State level', in: C. Adriaanse, F.J. van Ommeren, W. den Ouden and C.J. Wolswinkel (Eds.), Scarcity and the State The Allocation of Limited Rights by the Administration (Intersentia, 2016), 299. 
The negative integration achieved through Article 56 TFEU as set out above has also been complemented by positive integration, i.e. by EU legislation harmonizing national laws. ${ }^{58}$ Of significant importance has been the sectoral legislation, which regulated particular fields such as telecommunication, energy or financial services, the discussion of which is beyond the scope of this Chapter. ${ }^{59}$

In 2006, however, a general directive on services in the internal market was adopted, the Services Directive. ${ }^{60}$ This Directive became the subject of hitherto unprecedented levels of political contestation and protest, including French plumbers cutting of electricity to the holiday home of then internal market Commissioner Frits Bolkestein as they feared unfair competition from the dreaded 'Polish plumber' ${ }^{61}$ The main bone of contention was the 'country of origin principle' proposed by the Commission, which basically required mutual recognition of home state control. Such mutual recognition would remove many obstacles in one fell swoop, but was also perceived as undermining national protection of workers and service providers.

Under intense political pressure, the final Directive was severely watered down, many services excluded from its scope, and the country of origin principle scrapped. ${ }^{62}$ The resulting Directive does not add very much in terms of substantive free movement rights, as the key Article 16 on free movement largely repeats Article 56 TFEU. Nevertheless, the Services Directive has affected the application of the free movement of services and also provides several relevant procedural rights to service procedures in terms of administrative simplification and cooperation. ${ }^{63}$ Overall, however, the Directive is far from a success, and the EAC could certainly learn both from the botched political process and

$5^{8}$ See EU Chapter 9 for a discussion of this process in general.

59 See in this context also Chapter 16 on sectoral regulation in the EAC.

6o Directive 2006/123/EC of the European Parliament and of the Council on services in the internal market of [2006] L376/37. On the preceding debates, see Editorial Comments (2006) CML Rev., 307-311. On the evolution of the proposal, see J.-V. Louis and S. Rodrigues (Eds.) Les services d'intérêt général et l'Union européenne Brussels, 2006; O. de Schutter and S. Francq, "La proposition de directive relative aux services dans le Marché intérieur: reconnaissance mutuelle, harmonisation et conflicts de lois dans l'Europe élargie", (2005) CDE, 603-66o.

61 On the heated discussions surrounding the Directive see Editorial Comments (2006) CMLRev, 307-311.

62 C. Barnard, 'Unravelling the Services Directive', (2008) 45(2) CMLRev, 323. On the scope and application see for example Case C-341/14 Trijber ECLI:EU:C:2015:641.

63 See chapter II of the Services Directive. 
the eventual watered-down compromise. For example, one could first aim for the more limited but pragmatic objective of administrative simplification and cooperation alone, before trying any more radical steps such as introducing a country of origin principle.

\subsection{The Freedom of Establishment}

Article 49 TFEU contains the right to freedom of establishment, allowing natural and legal persons to establish themselves in other Member States:

Within the framework of the provisions set out below, restrictions on the freedom of establishment of nationals of a Member State in the territory of another Member State shall be prohibited. Such prohibition shall also apply to restrictions on the setting-up of agencies, branches or subsidiaries by nationals of any Member State established in the territory of any Member State.

Freedom of establishment shall include the right to take up and pursue activities as self-employed persons and to set up and manage undertakings, in particular companies or firms within the meaning of the second paragraph of Article 54, under the conditions laid down for its own nationals by the law of the country where such establishment is effected, subject to the provisions of the Chapter relating to capital. ${ }^{64}$

Article 54 TFEU then further clarifies the concept of a company or a firm:

Companies or firms formed in accordance with the law of a Member State and having their registered office, central administration or principal place of business within the Union shall, for the purposes of this Chapter, be treated in the same way as natural persons who are nationals of Member States.

'Companies or firms' means companies or firms constituted under civil or commercial law, including cooperative societies, and other legal persons governed by public or private law, save for those which are non-profit-making.

64 The vertical direct effect of Article 49 TFEU was established in Case 2/74 Reyners [1974] ECR 631. 
As a counterpart to the freedom to provide services, which is temporary in nature, establishment concerns a more permanent economic activity in another Member State. In the words of the CJEU, it allows an entity to 'participate, on a stable and continuous basis, in the economic life of a Member State other than his State of origin.' 65

Article 49 TFEU covers both private individuals (the self-employed), and the legal persons as defined in Article 54 TFEU. Moreover, it covers both primary and secondary establishment, which means that it not just enables one to move completely to a new state to start a new company, but also to set up a second office or to create agencies, branches or subsidiaries in another Member State whilst keeping the primary company in the own Member State. ${ }^{66}$ As with services, however, activities connected with the exercise of public authority are excluded. ${ }^{67}$

Just as the free movement of services, the freedom of establishment provides a right to market access and residence which also includes family members. ${ }^{68}$ Member States, therefore, are in principle prohibited to adopt any measures that restrict natural or legal persons from primary or secondary establishment. ${ }^{69}$ The justification of any such restrictions, as indicated above, is very similar to that of the free movement of services, requiring a legitimate aim that is pursued in a proportionate manner. ${ }^{70}$

One major debate unique to the freedom of establishment concerns the seat of undertakings and the freedom of companies under EU law to change their seat. In part this debate is caused by the fact that some Member States follow the real seat doctrine, whereas others follow the incorporation doctrine to determine the seat. So what happens, for example, if a company first establishes its real seat in Member State A, which follows the real seat doctrine, but then wants to move its seat to Member State B, which follows the incorporation

65 Case C-55/94 Gebhard ECLI:EU:C:1995:411, par. 25.

66 See for primary establishment for example Case 2/74 Reyners [1974] ECR 631 or Case C-411/o3 SEVIC [2005] ECR I-10805. For secondary establishment see Case 107/83 Klopp [1984] ECR 2971 or Case C-212/97 Centros [1999] ECR I-1459.

67 As an exception, this concept is interpreted very narrowly as well, cf. Case 42/92 Thijssen [1993] ECR I-4047.

68 See Article 7 of Directive 2004/38.

69 See for examples inter alia Case C-161/o7 Commission v. Austria ECLI:EU:C:2008:759, Case 208/oo Überseering [2002] ECR I-9919 or Case C-169/o7 Hartlauer ECLI:E U:C:2009:141.

70 Free movement of services and the freedom of establishment even share the same Treaty justifications, and many of the same rule of reason grounds apply to both as well. Note in this regard that the Services Directive, as set out above, also applies to establishment, further demonstrating the similarities and connections between both. 
doctrine, by merely incorporating its new seat in Member State B whilst keeping its real seat in Member State A? Although the case law is not fully clear yet, so far it seems that Member States remain free to determine which connecting factor they take into account for determining the initial seat as well as the connecting factor they require for maintaining a seat. ${ }^{71}$ For the EAC this question may become relevant as well, if differences in incorporation doctrines exist between Partner States, and if companies would increasingly start to use the freedom of establishment, for example for tax purposes.

71 See especially Case C-212/97) Centros [1999] ECR I-1459, Case C-208/oo) Überseering [2002] ECR I-9919, and Case C-210/o6) Cartesio [2008] ECR I-9641. 